\title{
Elementary School Teacher Development Policy in Yogyakarta City
}

\author{
Arif Rohman \\ Universitas Negeri Yogyakarta \\ Yogyakarta, Indonesia
}

\begin{abstract}
This research analyses policy on elementary school teacher development as implemented in Yogyakarta City. The research was conducted using a qualitative phenomenological approach. Respondents of research were forty stakeholders in elementary school teacher development policy including teachers, principals, officers from local government, and member of the local house of representative. Data was collected through in-depth interviews, document analysis, and focused group discussion (FGD). The results suggest that a policy on developing elementary school teachers has been implemented. However, such policy is viewed as highly related to local politics as consequences of local autonomy. Some teachers and member of local house of representative view policy on teachers as part of local government effort to strengthen political position. To some extends, the policy has positive impact in the form of teacher continuing education. However, the policy has negative effect such as uneven or even discriminative distribution especially among private schools.
\end{abstract}

Keywords: educational policy; elementary school teachers; development policy; local politics; the local house of representative.

\section{Introduction}

Teachers are the central figure in the education sector and are considered a major player in planning, preparing, and implementing the learning process in schools. Therefore, they are seen as a strategic figure in both macro and micro contexts. This is in line with the opinion of Siswoyo $(1996,2011)$ that teachers play a very strategic position in education by playing the combined roles of being managers, directors, organizers, coordinators, communicators, facilitators and stimulators at the same time. These make them very important in realizing educational and learning success and, on a broader scale, in determining the success of nation-building. Teachers also play the role as guardian in the process leading to the enlightenment of humanity (Hadisusanto, Sidharto, \& Siswoyo, 1995). 
A teacher's role in educating the next generation could not be separated from their relations and interactions with a various societal interest group. Spring (1993) mentions that their involvement in relationship formation allows them to become either a dominant or a sub-group. The interest groups highlighted include (1) politicians of political party, (2) education politicians (3) boards of education, (4) courts, (5) foundations, (6) corporate sectors, and (7) teachers' unions. These seven groups interact with each other in the formulation of relations for the education process.

The results of previous studies state that education is a prominent campaign issue for candidates in United States mayoral elections (Wong, 2006; Wagman, 2003). Wong (2006) mentions that most candidates promise not push for a takeover if the city's schools were to lose their accreditation. In general, some of the educational issues usually raised include strengthening leadership in public education, school reform, and improving school quality. A similar situation could be seen in Indonesia where many experts observed that in every election season, educational issues are always an essential part of candidates' campaign. Furthermore, teacher development in the form of training in Indonesia has historical background with United States (Abbott, 2017; Suwignyo, 2017).

Indonesia is currently under a local autonomy regime which imply that local leaders are chosen directly through general election. During the campaign, teachers are also important stakeholders that every candidate should seek their voices. Teachers as part of education environment as a whole are subject to such political campaign and promises by local leader candidates (Prihatini, 2011; Wisudawati; 2014). After being appointed, the candidates may or may not directly implement their political promises in the form of solid policy. And when the policy is made it may impact teachers the way they expected or not due to some circumstance in the local politics or schools context.

As a city associated with its strength in education and culture, Yogyakarta City also faces many issues in relation to local politics. The city is always seen as educational barometer in Indonesia thus policy on teachers in the area can be viewed as example for others. Based on the explanations above, this research aimed to reveal the strategic education policy planning along with the motives behind it in developing elementary school teacher in Yogyakarta City. It analyses how local government manage specific policy to improve teachers quality, how this policy works along political motives, and how it impact teachers quality in Yogyakarta City. To ensure the quality of research the structure of paper is described below. This part describes the background of the study, along with previous relevant works. Part two deals with the research method. Part three explains the results and its discussion. Part four concludes the study.

\section{Literature Review}

There are a series of interrelated studies on educational policy with respect to Indonesia cases. Baedhowi's (2004) research has succeeded in uncovering decisive actors in formulating and implementing education policies using the political theory of education to be the heads of government in the regions 
(mayor), a local house of representative, and the education service officials. However, this indicates inequality that creates a pattern of dominant and subdominant relationships between them. The mayor, as the ruler, dominates the education service apparatus using the local house of representative followed by the principal and then the teacher at the bottom of the ladder. In social psychology, this dominative relations pattern can have an impact on the teacher's performance when carrying out their professional responsibilities.

Rafiqie's (2008) research made use of a bureaucratic procedural view to reveal the procedures and work steps involved in implementing education policies in the regions. The process was observed to start from continuing socialization about the implementation management through internal coordination by structural officials of the education office as well as external ones by the Head of Service and District Government Officials. The process of preparing education policies starts from the meeting held in schools followed by discussion in different work units of each agency, considered at the official meeting, and ends at the Regional Development Planning Conference (Musyawarah Perencanaan Pembangunan Daerah abbreviated Musrenbangda). This is supported by the bureaucratic education structure that involves a clear division of labor and supervision, both directly and indirectly. The whole process is based on the SOP made by the regent as the head of the region.

Irine (2009) found that education policies made by the government experience a dynamic process in the structure and culture that contribute to their successful implementation in schools through the use of educational policy theory. It was also observed that the creativity of the school is necessary for this process through the utilization of their cultural, social, intellectual, and economic capitals. This research implies importance of policy on education to schools and teachers as main stakeholders in improving educational quality.

Another research conducted through the use of a functional view by Supriyanto (2010) found a political relationship between teachers and regional authorities in taking mutual benefits. This relationship was discovered not to be confrontational but collaborative or symbiotic. This is evident in the institutional expansion of educational services from one agency to two education offices, namely the Elementary Education Office (Dinas Pendidikan Dasar abbreviated Dikdas), and Secondary and Non-Formal Education Service Office (Dinas Pendidikan Menengah dan Non-Formal abbreviated Dikmenof).

Another research conducted through a critical theory perspective by Rohman (2013a) revealed that teachers had been politicized by regional authorities for political interests. This was designed as a 'veiled practice' to 'win support' from the broader community because of the assumption that teachers hold a 'strategic position' in society. The politics of domination by regional authorities over teachers is in two forms: political co-optation and charity. The former is carried out through the mastery of teacher professional organizations and the placement of many government bureaucrats in the teacher association core management. Meanwhile, the latter includes scholarship donation and welfare improvement incentive tactics (Rohman, Muhadjir, \& Suyata, 2013). 


\section{Research Method}

This research was conducted by applying a qualitative phenomenological approach because of its ability to develop theories and hypotheses based on empirical findings. It allowed the researcher to be separated from the subject and also made him useful in revealing the subject's intentionality. It also gave him the opportunity of being a facilitator or mediator in developing moral values among teachers. The approach was based on the critical theories of Michel Foucault (Afandi, 2012; Mudhoffir, 2013) and Antonio Gramsci (Williams, 1960; Mayo, 2008).

The subjects of the study were 30 elementary school teachers, three elementary school headmasters, two daily administrators of Teachers Association of Republic of Indonesia (Persatuan Guru Republik Indonesia abbreviated PGRI) Yogyakarta, two daily administrators of educational NGOs, Head of Local Office of Ministry of National Education, and one member of the local house of representative from Commission D. Therefore, 40 people in total were respondents in this research. They were chosen purposively with the following criteria: (1) acknowledge a lot about the theme of the research, (2) experience more than 5 years in the field of teacher training, (3) native person from Yogyakarta. In initial stage, researcher contacts potential respondents and inform them about the research. Once respondents agree to be part of the research, their names were listed for further step of research.

This research was conducted using some procedural steps. It began with an initial survey action which was conducted to find out the initial portrait of the general policies of Yogyakarta city government in developing elementary school teachers as well as the planning, motives, and impact for their development.

Data was collected through in-depth interviews, document analysis, and focused group discussion (FGD). The in-depth interviews were used to explore the subjective experience of critical informants about verbal data. Document analysis was conducted to assess employee affair data, official letters, and various city government decisions regarding teachers. The FGD was used to develop a format for teacher empowerment through their professional association and educational NGOs. However, the triangulation of methods and sources was done to achieve acceptability and credibility.

The data collected was analyzed using qualitative phenomenological research, as proposed by Creswell (2007). This was done through six processes of (a) managing data, (b) reading and memorizing, (c) describing, (d) classifying, (e) interpreting, and (f) visualizing.

\section{Results and Discussion}

\subsection{Strategic Policy Planning for Elementary Teacher Development}

In general, the strategic policies carried out by the Local Office of Ministry of National Education in Yogyakarta City in the education sector are (a) to organize and evenly distribute civil service teachers with reference to the Regulation of Ministry of National Education Number 20 in 2010 Concerning Norms, 
Standards, Procedures and Criteria in the Field of Education; (b) arrange the teacher requirements planning at the city level education unit; (c) structuring and even distribution of civil service teachers is done if the city government has carried out the required planning and teacher optimization analysis at the education unit level; (d) Teachers in education units organized by the city government can be transferred between educational units, levels, types of education, between districts/cities, and provinces; (e) The Ministry of Education and Culture coordinates and facilitates the transfer of the teachers.

This is in agreement with Saleh's theory that in the era of regional autonomy, each autonomous region has the right to regulate and govern its region. This theory provides the regions with the right of initiative and willingness as obtained from the central government (Hendratno, 2009). Likewise, Wayong states that regional autonomy is the freedom to maintain and advance regional special interests with its finances to determine its law, and self-government (Hendratno, 2009).

The strategic policies carried out by the Local Office of Ministry of National Education in Yogyakarta City as regards teachers were carried out based on coordination procedures such as (a) socialization of dissemination programs for them; (b) verification of data and analysis of their needs; (c) provision of maps informing them about their advantages and/or shortcomings with copies submitted to the National Civil Service Agency (Badan Kepegawaian Nasional abbreviated $\mathrm{BKN}$ ); (d) transferring them between educational units and regions; (e) provision of funds for their transfer; (f) coordination with the office of the ministry of religion for guidance when it comes to transferring them.

Requirements for teachers are planned based on the reports that contain the number of teachers according to their type, number of students, study groups and hours for each subject with reference to the curriculum structure and adjusted to the type of program being run by the school from the education unit after which it would be submitted to the provincial education office to be followed up. The planning scope for teachers includes the formulation of types and numbers of teachers needed. This is carried out at the national level with the number based on each education office.

In the recruitment process, the education office in Yogyakarta would first consider the characteristic, duties, and activities of the teachers. They are classified into three: (a) Class teachers or teachers who have full duties, responsibilities, authority, and rights in the learning process of all subjects in a particular class both in kindergarten (Taman Kanak-kanak abbreviated TK, or Taman Kanan Luar Biasa abbreviated TKLB) and elementary school (Sekolah Dasar abbreviated SD, or Sekolah Dasar Luar Biasa abbreviated SDLB) and other equivalent formal education units; (b) Subject teachers or teachers who have duties, responsibilities, and authority, and full rights in the learning process in one subject that is mastered; (c) Guidance and counselling/counsellor teachers who have full duties, responsibilities, authority and rights in guidance and counselling activities for a number of formal education unit students at the level of primary and secondary education. 
The calculation of the needs for elementary school class teachers is carried out with the following considerations (a) Each study group or class consists of 20-32 students, (b) Each class is administered by one class teacher, (c) Each elementary school must provide religious and physical and health education teachers, (d) the religious and physical and health education teachers should teach in the calculation of 24-hour face-to-face session on a weekly basis, (e) Every elementary school must provide religious teachers in accordance with the various types of religion embraced by students, (f) If there are children with special needs and/or elementary school holding an inclusive education program, then they must provide at least one individual education teacher for six classes, with the calculation of hours equivalent to the class teacher.

To optimize the fulfilment of teacher requirements, the provisions include (a) Lack of classroom teachers can be overcome by (1) accepting transfer teachers from other education units from the same district or other districts, (2) new teacher appointment/recruitment, (3) Multi-grade learning for specific regions in accordance with applicable regulations. (b) Overload of class teachers can be overcome by: (1) Transferring teachers to other education units, (2) Transferring teacher functions/professions, by applicable regulations (3) Early retirement, by applicable regulations. With the policy above, the increase in the number of teachers, especially elementary school teachers, is relatively fulfilled. It would increase the student-teacher ratio and make it approach the ideal condition, especially those that are in the northern area of Yogyakarta City.

Furthermore, the teacher certification in Yogyakarta has been running relatively well, even though it is still constrained by certification administration because of the involvement of too many agencies. As a result of the policy that requires increased teacher certification, their qualifications in achieving a minimum education level of bachelor or diploma have increased. The Regulation of Yogyakarta Mayor Number 24 of 2014 concerning the Yogyakarta City Regional Development Work Plan for 2015 has included an increase in the percentage of teachers with a bachelor's or 4-diploma qualification. There is a very rapid development trend regarding the percentage of teachers in the city of Yogyakarta who has met bachelor or diploma qualifications as mandated by Law No. 14 of 2005 concerning Teachers and Lecturers. In 2007, there were $62.30 \%$, in 2008 it increased to $69.01 \%$, in 2009 to $69.64 \%$, in 2010 to $72.18 \%$, in 2011 there were $76.26 \%$, and in 2012 it increased higher to $84,30 \%$.

The education policy process conducted by the education office was done through a process of initiation, accommodation, formulation, and legislation. The initiation process was carried out through the socialization of all units starting from the section, integrated service unit (unit pelayanan terpadu abbreviated UPT), to the education unit. The accommodation was done by absorbing aspirations, formulation by forming a team to draw up a draft policy that was forwarded to the regional secretariat and commission in the local house of representative while the legislation was done by submitting it to the authorities involved in the legislative process, which are the local house of representative of Yogyakarta City.

In preparing the education policy, the government engaged in the preparation, discussion, and ratification. The stage of preparation was done by compiling 
academic manuscripts until the realization of the draft of the regional regulations. The approval phase involved a discussion about the draft regulation in local house of representative along with relevant officials to enter the regional legislation program. The last stage was the ratification which has to do with several discussions at the plenary meeting held by the local house of representative and Mayor.

However, some members of the local house of representative of Yogyakarta City perceived all the planning of strategic education policy carried out by the Education Office in Yogyakarta City as described above differently. They believe that the policies place the teachers as the sole object of policy without inviting them to any dialogue with the government. Therefore, they deeply regretted it and believed that such policies might weaken the teachers.

The perception is in line with the views of some teachers who frankly admit that there has been much deceitfulness in teacher training including discrimination on particular schools, uneven distribution of certification allowances, deduction of the allowances for one month due to one day absence, inequality in treatment of private and public schools, and coercion of some teachers to become school principals.

Theoretically, distortion is often experienced in the regional policies and according to Silalahi (1989), this is caused by (1) The over-lapping of policy objectives produced or caused by misunderstandings, chaos, or conflict of values, (2) The participation of so many actors with overlapping authority, (3) Resilience of implementers, ineffectiveness, and inefficiency in implementing the policy.

The distortion theoretically creates disappointment from marginalized parties. Coser termed this suspense and classified it as realistic and non-realistic. The realistic suspense is derived from the disappointment over various particular demands and estimated possible benefits of each group in the relationship. It is mostly observed from the group that was disappointed. On the other hand, nonrealistic suspense does not originate from various antagonistic rival goals but from the need to ease tensions, at least from one party (Ritzer, 1996; Dodi, 2017).

\subsection{Political Motives behind Education Policy}

The policy of the Government of Yogyakarta City regarding teachers' development, as indicated by the local house of representative and some teachers, is considered to contain certain political motives. Some members of the local house of representative of Yogyakarta City view teachers only as political objects for political interest. However, teachers need to be approached with a dialogical humanist approach, not by threats. Many teachers claim to be forced in many ways. For instance, some teachers are forced to become school principals. This certainly shows that the policy pattern is inappropriate and oppressive. Therefore, to maintain the importance of teacher quality, a local house of representative expects that executives avoid attempts to politicize teachers. 
The same perception was also shared by the teachers, who revealed that the education policy has a certain motive. This is evident in the injustices committed by the department such as awarding best-performing teachers to those that are well-known by the officials, paying more attention to some favourite public schools and marginalizing the poor and private ones. Moreover, according to the teachers, the political motives of the government are reflected in their uneven distribution of policies and various regional and mayoral regulations are also considered to be repressive. They also criticized the "house demolition policy" of the government which was intended at replacing education officials and old school principals as a result of the old mayor's inheritance with new officials.

These show that there are certain motives behind education policy, even though this was denied by the Yogyakarta city government. This is by a theory stated by Spring (1993) that the process of power relations between teachers and rulers tends to be lame. The ruling group, which in this case is the Yogyakarta city government, tends to try to use its power to co-opt teachers as a tool of power. Teachers are almost always marginalized and tend to be powerless under the pressure of dominant power. This is in line with the thoughts of Collins (1979) that teachers and schools have been directed by the dominant power to be used as a tool to perpetuate the regime power.

Baedhowi (2004) agreed to these submissions by stating that the decisionmaking process for solving educational problems in the regions, when viewed from the perspective of policy initiation, is not objectively determined by requirements analysis, but by the interest of regional policy-making actors or officials. The educational policies formulated by officials in the coverage areas tend to be for a shorter term, and this makes them less relevant to the needs of the community.

\subsection{The Arising Impact from Political Motives}

These political motives have both positive and negative impacts. The positive ones include increase in the quality of elementary school teachers which are achieved through the seven programs of advanced study education to the higher levels, fostering teacher working groups (kelompok kerja guru abbreviated KKG), implementing teachers activity unit (unit kegiatan guru abbreviated UKG) and teacher certification, innovation and teacher creativity competitions, increasing teacher activity in KKG, education and training, as well as improving teacher welfare.

Another positive impact is the improvement of teachers' education qualifications to a Bachelor or Diploma. Teachers in the city of Yogyakarta increased their academic qualifications between 2007 and 2012. In 2007, the percentage of teachers that met Bachelor or Diploma qualification was $62.30 \%$, and it was recorded to have increased to $84.3 \%$ in 2012. These positive impacts are good indictors for policy implemented by local government of Yogyakarta City for teachers.

Besides the positive impact, the negative ones include the disappointment of a small number of teachers, especially private schools, private teachers, low-level 
employees, and others, who felt discriminated. Another thing is the uneven distribution and marginalization of private school teachers because of their religion. Uneven distribution occurs mostly in term of educational supports for teachers directly or directly.

The disappointment of some teachers came because of various regional and mayor regulations, which are considered to be repressive, arrogant, and pressing on them. For example, Mayor Regulation or Perwal number 84 of 2012 and number 837 of 2014 concerning the granting of study permits and learning assignments as well as the issuance of Regulation No. 43 of 2012 concerning additional income for employees, which is considered very discriminatory. The Government of Yogyakarta City regulates the deduction of public employees if they do not enter six days without permission while the teachers' is just one day without permission.

This finding implies that at some point bureaucratic problem can restrict policy on teachers. Nielsen (1998) has previously discussed the matter in the context of national education policy. Such situation may also appear in local context for teacher development in Yogyakarta City. To some extend bureaucratic problem has become a key reason for teachers in reaching government position. The have concern that educational policy should be managed by the right person who in this context are teachers (Rohman, 2013b).

\section{Conclusion}

It can be concluded from this research that there is a strategic policy planning for the development of elementary teacher; and that there are political motives behind these policies by the Yogyakarta city government. The strategic policies, which were formulated by the Education Office, are prepared in order to facilitate the transfer of teachers through several forms of activities such as program socialization, verification of data and requirements analysis, provision of deployment maps and funds for transfers, transfers between educational institutions and regions, and coordination with relevant agencies. However, these policies have been criticized for being placing teachers as mere policy objects and weakening them by some members of the local house of representative of Yogyakarta City.

The policy has also been observed to be formulated based on political motives. Therefore, teachers should be freed from practical political interests, and approached with a dialogical humanist approach, rather than through threats. Furthermore, there is a positive and negative impact arising from political motives. The positive impact includes the equal distribution, increasing education qualifications to undergraduate level, quality, number of certified teachers, and welfare while the negative ones include the disappointment of a small number of teachers, especially private schools, private teachers, low-level employees, and others, who felt discriminated. Another thing is the uneven distribution and marginalization of private school teachers because of their religion. 
This research analyses policy implemented to elementary schools teachers in Yogyakarta City. It has many strong evidence of result findings as discusses above. However, some limitations should also be acknowledged especially in sample choices. Further direction in the same research should consider other type of schools teachers as potential respondents to grasp a larger findings on educational policy addressed by local government. Furthermore, a comparative analysis with other close or related city may help to understand the policy from a wider perspective.

\section{Acknowledgment}

The author thanks Universitas Negeri Yogyakarta for financial support for this research. The author bears responsibility for findings of the research.

\section{References}

Abbot, A. (2017). Nature of the Indonesia-United States education relationship, Globalisation, Societies and Education, 15(4), 545-560. doi:0.1080/14767724.2016.1195724.

Afandi, A. K. (2012). Konsep kekuasaan Michel Faucault [Concept of power according to Michel Faucault], Teosofi: Jurnal Tasawuf dan Pemikiran Islam, 2(1), 131-149. Retrieved from http://teosofi.uinsby.ac.id/index.php/teosofi/article/view/82.

Baedhowi. (2004). Implementasi kebijakan otonomi daerah bidang pendidikan: Studi kasus di Kabupaten Kendal dan Surakarta [Implementation of autonomy policy in education: Case study in Kendal and Surakarta]. Jakarta, Universitas Indonesia, Ph.D. Dissertation.

Collins, R. (1979). The credential society: An historical sociology of education and stratification. New York: Academic Press.

Creswell. J.W. (2007). Qualitative inquiry \& research design: Choosing among five approaches (Second edition). London: Sage Publications.

Dodi, L. (2017). Sentiment ideology: Membaca pemikiran Lewis A. Coser dalam teori fungsional tentang konflik [Ideology sentiment: Reading Lewis A. Coser thought in functional theory about conflict], Jurnal Al-'Adl, 10(1), 104-124.

Hadisusanto, D., Sidharto, S., \& Siswoyo, D. (1995). Pengantar ilmu pendidikan [Introduction to educational sciences]. Yogayakarta: FIP IKIP Yogyakarta.

Hendratno, E.T. (2009). Negara kesatuan, desentralisasi, dan federalisme [Nation-state, decentralization, and federalism]. Yogyakarta: Graha Ilmu.

Irine, S. (2009). Desentralisasi pendidikan dan dinamika sosial [Educational decentralization and social dynamics]. Yogyakarta, Universitas Gajah Mada, Ph.D. Dissertation.

Mayo, P. (2008). Antonio Gramsci and his relevance for the education of adults, Educational Philosophy and Theory, 40(3), 418-435. doi:10.1111/j.14695812.2007.00357.x

Mudhoffir, A.M. (2013). Teori kekuasaan Michel Foucault: Tantangan bagi sosiologi politik [Theory of power by Michel Foucault: Challenges for political sociology], Masyarakat: Jurnal Sosiologi, 18(1), 75-100. doi:10.7454/mjs.v18i1.3734.

Nielsen, H. D. (1998). Reforms to teacher education in Indonesia: Does more mean better?, Asia Pacific Journal of Education, 18(2), 9-25. doi:10.1080/0218879980180203 
Prihatini, C. E. (2011). Penggunaan simpul-simpul komunikasi sosial sebagai strategi kampanye [The use of social communication channels as campaign strategy], Jurnal Ilmu Komunikasi, 8(1), 81-102. doi:10.24002/jik.v8i1.183.

Rafiqie, M. (2008). Implementasi kebijakan pendidikan di era otonomi daerah (Studi multi situs pada tiga kabupaten di Kawasan Tapal Kuda) [Implementation of educational policy in local autonomy era (A multi sites study in three regencies in Tapal Kuda Area)]. Malang, Universitas Negeri Malang, Ph.D. Dissertation.

Ritzer, G. (1996). The McDonaldization thesis: Is expansion inevitable?, International Sociology, 11(3), 291-308. doi:10.1177/026858096011003002.

Rohman, A. (2013a). Guru dalam pusaran kekuasaan [Teachers in the midst of political power]. Yogyakarta: Aswaja Pressindo.

Rohman, A. (2013b). Kekuasaan guru dalam birokrasi pemerintahan daerah [Teachers power in local government bureacracy], Jurnal Penelitian Humaniora, 18(2), 121$130 . \quad$ Retrieved from https://journal.uny.ac.id/index.php/humaniora/article/view/3167

Rohman, A., Muhadjir, N., \& Suyata. (2013). Dinamika relasi politik antara otonomi guru dan dominasi kekuasaan [The dynamics of political relation between teachers autonomy and power domination], Jurnal Pembangunan Pendidikan: Fondasi dan Aplikasi, 2(2), 101-113. doi:10.21831/jppfa.v2i2.2622.

Silalahi, U. (1989). Studi tentang ilmu administrasi [Study on administrative sciences]. Bandung: CV. Sinar Jaya.

Siswoyo, D. (1996) Ilmu pendidikan dalam tantangan [Educational sciences within challenges], Cakrawala Pendidikan: Jurnal Ilmiah Pendidikan, 6(1), 1-13.

Siswoyo, D. et al. (2011) Ilmu pendidikan [Educational sciences]. Yogyakarta: UNY Press.

Spring, J. (1993) Conflict of interests: The politics of American education. New York: Longman.

Supriyanto. (2010). Dinamika politik pengambilan kebijakan pembentukan dua dinas pendidikan di Kabupaten Bantul [The dynamics of decision-making in creation of two educational offices in Bantul]. Yogyakarta, Universitas Negeri Yogyakarta, Undergraduate Thesis.

Suwignyo, A. (2017). The American influence in Indonesian teacher training, 1956-1964, History of Eduction, 46(5), 653-673. doi:10.1080/0046760X.2017.1328614.

Wagman, J. (2003). Power brokers play role in campaign for school reform. Saint Louis PostDispatch.

Williams, G.A. (1960). The concept of 'egemonia' in the thought of Antonio Gramsci: some notes on interpretation, Journal of the History of Ideas, 21(4), 586-599. doi: $10.2307 / 2708106$.

Wisudawati, D. N. R. (2014). Isu pendidikan dalam kampanye politik [Educational issues in political campaign], Jurnal Pendidikan dan Kebudayaan, 20(4), 579-587. doi:10.24832\%2Fjpnk.v20i4.167.

Wong, K.K. (2006). The political dynamics of mayoral engagement in public education, Harvard Educational Review, 76(2), 164-177. doi:10.17763/haer.76.2.g07306666x605852. 